\title{
Solid waste management response of selected public secondary school science teachers
}

\author{
Van Ryan Kristopher R. Galarpe ${ }^{1, *}$, Brawner Brian L. Heyasa ${ }^{2}$ \\ ${ }_{1}^{1}$ Physics Department, University of Science and Technology of Southern Philippines, Cagayan de Oro 9000, Philippines \\ ${ }^{2}$ Department of Electronics Engineering, University of Science and Technology of Southern Philippines, Cagayan de Oro 9000, \\ Philippines
}

\section{A RT I C LE IN F O}

\section{Article history:}

Received 19 January 2017

Received in revised form

27 May 2017

Accepted 3 June 2017

Keywords:

DepEd

RA 9003

Solid waste management

\begin{abstract}
A B S T R A C T
This paper tried to descriptively determine the practice of secondary public schools in Cagayan de Oro Philippines, vital sector to initialize information drive in students and community. This was conducted to identify the extent of the Department of Education (DepEd) and Republic Act 9003 mandate on SWM to public secondary schools. A survey questionnaire was administered to 45 science teachers and followed by ocular visit to surveyed schools. Overall, the survey showed positive level of awareness, attitude, and practices of teachers towards SWM. Practices however were selectively better in some schools through establishing recycling and composting options. Generally, the absence of a recommended material recovery facility (MRF) was common. Present findings served as basis to review existing policy framework in DepEd and the local government units (LGUs) to support SWM in educational sectors.
\end{abstract}

(C) 2017 The Authors. Published by IASE. This is an open access article under the CC BY-NC-ND license (http://creativecommons.org/licenses/by-nc-nd/4.0/).

An integral part of this policy is the ideal involvement of public secondary schools as institutions situated in every community clusters. However, recent studies revealed poorly managed solid wastes (SW) evidenced by the use of landfills and unregulated dumpsites (Galarpe and Parilla, 2012; Galarpe and Parilla, 2014; Galarpe, 2015; Su, 2008; Su, 2005; Cortez and Ching, 2014; Ejares et al., 2014) in the country. This pressing condition essentially showed gaps in the local institutional implementation of the policy. The Department of Education (DepEd) is considered significant in policy implementation along with the LGUs. The institution accommodates the bulk of younger population and must be given proper training on SWM. Further, schools with better SWM practice showed positive response by providing SW recycling options (Smyth et al., 2010; Mbuligwe, 2002; Mason et al., 2003; Malakahmad et al., 2010; Kelly et al., 2006; Felder et al., 2001; De Vega et al., 2003; 2008). Consequently, schools can implement a structure to mitigate SWM issues. Locally, the city division of DepEd on 2015 issued a mandate (Memorandum 696) to participate in SWM and waste segregation in coherence with the local government.

The implementation however of this mandate to respective schools was not measured. It is with this purpose that this study was conducted, to identify qualitatively and descriptive the implementation of RA 9003 and DepEd Memo 696 to selected public 
secondary schools in Cagayan de Oro. The objectives of the study were to determine the level of (i) awareness; (ii) attitude; and (iii) practices among selected secondary public school teachers. The study similarly, aimed to identify gaps and best practices of SWM practices in participating schools.

\section{Materials and methods}

\subsection{Framework of the study}

The study was mainly descriptive survey aimed to determine qualitatively the level of awareness, attitude, and practices among selected science teachers from public secondary schools in Cagayan de Oro, Philippines (Fig. 1). These parameters were assessed as basis for advocacy development program (Cruz and Tantengco, 2017), and policy checking on SWM. In other studies these parameters were valuable to draw baseline data for environmental-demographic analysis (Babaei et al., 2015; Licy et al., 2013; Ugulu et al., 2013; Ifegbesan, 2010; Ifegbesan, 2011)

Science teachers were chosen owing to fit environmental awareness. Environmental literacy of teachers was also seen essential in establishing the baseline environmental education policy (Liu et al., 2015) like SWM.

\subsection{Conduct of the study}

The study was initially conducted in the University of Science and Technology of Southern Philippines (USTP) during the lecture series orientation among science teachers. A total of 45 science teachers from 21 public secondary schools were purposively identified as the study respondents. Ocular visits were also conducted in their respective schools to verify the existing practices.

\subsection{Survey questionnaire}

The survey questionnaire was anchored from the study of Licy et al. (2013), Ugulu et al. (2013), Ifegbesan (2010), and Ifegbesan (2011) with modifications to fit for the study locale. The survey questionnaire composed of three measures, namely, awareness (11 questions), practices (5 questions), and attitude (5 questions), respectively.

\subsubsection{Awareness questions}

1. Are you aware about Republic Act 9003 or Ecological Solid Waste Management Act of 2000?

2. Do you have solid waste management topics/lectures/curriculum in your school?

3. Do you have material recovery facility in your school?

4. Did you ever attend any awareness program conducted by local authority/ school regarding house hold waste management?
5. Do you know about segregation of waste?

6. Do you know the principle of waste minimization?

7. Do you know the complications of improper waste management?

8. Do you think that local authorities have a role to play in the management of house hold waste/school waste?

9. Do you know the effective mechanism for house hold waste/school waste management?

10. Are you aware about electronic/electrical waste?

11. Do you know how to dispose the electronic/electrical waste?

\subsubsection{Attitude questions}

1. Improper waste disposal is a threat to the environment.

2. Solid waste management is the sole responsibility of school

3. Solid waste management is the sole responsibility of local authority.

4. I am also responsible for the generation of solid waste.

5. I also have a role to minimize the solid waste.

\subsubsection{Practices questions/statements}

1. Are you committed to minimize the waste?

2. Do you segregate school wastes?

3. Do you have solid waste bins for biodegradable and non-biodegradable?

4. Do you throw your waste outside the school/perimeter?

5. Do you see garbage on roadside while coming to school?

To extrapolate an estimate of their SWM practices, three further questions were asked which included: (i) the type of SW; (ii) the amount of waste generated daily; (iii) type of disposal method.

\subsection{Data analysis}

All results were expressed using descriptive statistic. The mean, percent, and standard deviations were presented to summarize the response.

\section{Results and discussion}

\subsection{Awareness}

Overall the teachers were aware with the abiding government policy (RA 9003) on SWM. This was evidenced by $100 \%$ positive response (Table 1 ).

Teachers were similarly incorporating SWM discussions in their respective classes as part of curriculum instructions, although, about five responded negatively. Integration of SWM to curriculum is enforcement to SWM legislation (Imam et al., 2008).

The teacher's awareness however towards MRF (56\%) was low attributed to absence of MRF facility 
in both community and school. Similarly, awareness towards e-waste (78\%) was low with $38 \%$ of the teachers being unaware about e-waste disposal. The result supports the previous findings of Cultura et al. (2013) that households in Cagayan de Oro were unaware about e-waste disposal owing to absence of collection mechanism. Present findings can also be associated to little trainings attended about SWM ( $22 \%$ of the teachers).

Table 1: Level of awareness among public secondary school teachers towards SWM

\begin{tabular}{|c|c|c|c|}
\hline Questions & Yes & No & Not sure \\
\hline $\begin{array}{c}\text { Are you aware about Republic Act } 9003 \text { or Ecological Solid Waste } \\
\text { Management Act of 2000? }\end{array}$ & $45(100 \%)$ & 0 & 0 \\
\hline $\begin{array}{c}\text { Do you have solid waste management topics/lectures/curriculum in } \\
\text { your school? }\end{array}$ & $\begin{array}{c}40 \\
(89 \%)\end{array}$ & $5(11 \%)$ & 0 \\
\hline Do you have material recovery facility in your school? & $25(56 \%)$ & $19(42 \%)$ & $1(2 \%)$ \\
\hline $\begin{array}{l}\text { Did you ever attend any awareness program conducted by local } \\
\text { authority/ school regarding house hold waste management? }\end{array}$ & $35(78 \%)$ & $10(22 \%)$ & 0 \\
\hline Do you know about segregation of waste? & $44(97 \%)$ & 0 & $1(3 \%)$ \\
\hline Do you know the principle of waste minimization? & $41(91 \%)$ & $4(9 \%)$ & 0 \\
\hline Do you know the complications of improper waste management? & $45(100 \%)$ & 0 & 0 \\
\hline $\begin{array}{l}\text { Do you think that local authorities have a role to play in the management } \\
\text { of house hold waste/school waste? }\end{array}$ & 43 (96\%) & $2(4 \%)$ & 0 \\
\hline $\begin{array}{l}\text { Do you know the effective mechanism for house hold waste/school } \\
\text { waste management? }\end{array}$ & $43(96 \%)$ & $2(4 \%)$ & 0 \\
\hline Are you aware about electronic/electrical waste? & $35(78 \%)$ & $10(22 \%)$ & 0 \\
\hline Do you know how to dispose the electronic/electrical waste? & $28(62 \%)$ & $17(38 \%)$ & 0 \\
\hline
\end{tabular}

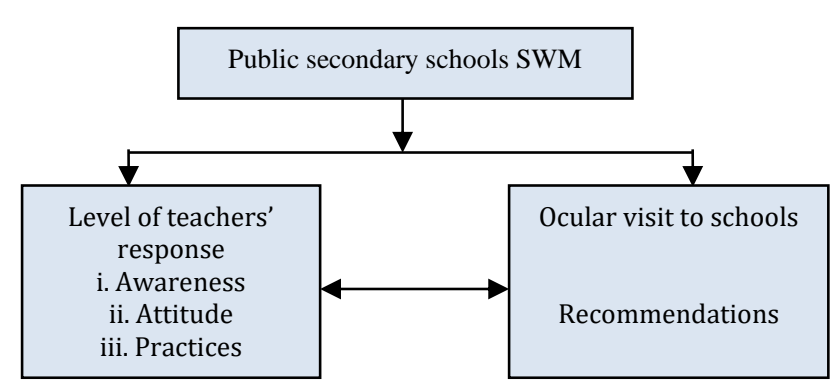

Fig. 1: Framework of the study

Participation to training programs on SWM and waste disposal method is a vital factor for influencing attitude towards SWM (Begum et al., 2009).

\subsection{Attitude}

About $98 \%$ of the surveyed teacher's recognized improper waste disposal as threat to the environment (Table 2).

Sparingly $27 \%$ and $14 \%$ of the teachers perceived that SWM be the sole responsibility of the school and the local authority. Teachers generally agreed that they similarly have the responsibility on SWM (93\%) and to minimize SW generation (95\%). Source reduction, reuse and recycling measures, frequency of waste collection, staff participation in training programs and waste disposal method are factors to affect attitude towards SWM (Begum et al., 2009).

Table 2: Attitude of public secondary school teachers towards SWM

\begin{tabular}{cccc}
\hline & Yuestions & No & Not sure \\
\hline Improper waste disposal is a threat to the environment. & $44(98 \%)$ & $1(2 \%)$ & 0 \\
Solid waste management is the sole responsibility of school. & $12(27 \%)$ & $33(73 \%)$ & 0 \\
Solid waste management is the sole responsibility of local authority. & $14(31 \%)$ & $31(69 \%)$ & 0 \\
I am also responsible for the generation of solid waste. & $42(93 \%)$ & $2(4 \%)$ & $1(3 \%)$ \\
I also have a role to minimize the solid waste. & $45(100 \%)$ & 0 & 0 \\
\hline
\end{tabular}

\subsection{Practices}

All teachers were found to reduce their waste generation in schools (Table 3) however this commitment was differed with existing practices. About 22\% of teachers do not segregate school SW, reflecting poor practice. A total of $27 \%$ of the teachers responded an absence of biodegradable and non-biodegradable waste bins in schools, resulting to throwing of SW outside the school perimeter (67\%).

Present result is attributed to lack of appropriate waste bins in schools to encourage better recycling behavior (De Vega et al., 2003; 2008; Smyth et al., 2010; Kelly et al., 2006; Malakahmad et al., 2010; Mason et al., 2003). Throwing of SW outside school perimeter will result to litter and spillages in schools (Elemile and Benjamin, 2011). It was also evident that SW generated in schools was mainly plastics, papers, food waste, and polyethylene (PET) bottles (Fig. 2). Present result was in agreement with waste characterization studies in the Philippines revealing plastics and papers as dominant SW (Paul et al., 2012; Zurbrugg, 2002; Bernardo, 2008; Galarpe and Parilla, 2014).

The perceived amount of SW in schools were above $1 \mathrm{~kg}$ daily, followed by $<1 \mathrm{~kg}$ and $0.5 \mathrm{~kg}$ to $1 \mathrm{~kg}$ (Fig. 3). This volume of waste is expected owing to the large population of students in public secondary schools.

While surveyed teachers responded that recycling was the common practice for disposal (Fig. 4), this however do not reconcile with previous data about throwing SW outside school perimeter and lack of segregation practice (Table 3). 
This may be an imposed awareness drive being claimed as a practice. In some schools, they have improvised recycling waste bins intended for PET bottles mainly found in school gates and canteens which were perceived as recycling option for the entire school. Further data presents throwing to trash bins as the second option for disposal method, although there was lack of two bins for biodegradable and non-biodegradable. Present findings on disposal method through throwing to trash bins and burning were in agreement with socioeconomic studies of adjacent communities in disposal sites (Galarpe and Parilla, 2014; Galarpe, 2015).

Table 3: Practices of public secondary school teachers towards SWM

\begin{tabular}{|c|c|c|c|}
\hline Questions & Yes & No & Not sure \\
\hline Are you committed to minimize the waste? & $45(100 \%)$ & 0 & 0 \\
\hline Do you segregate school wastes? & $35(78 \%)$ & $10(22 \%)$ & 0 \\
\hline Do you have solid waste bins for biodegradable and non-biodegradable? & $33(73 \%)$ & $12(27 \%)$ & 0 \\
\hline Do you throw your waste outside the school/perimeter? & $15(33 \%)$ & $30(67 \%)$ & 0 \\
\hline Do you see garbage on roadside while coming to school? & $41(91 \%)$ & $4(9 \%)$ & 0 \\
\hline
\end{tabular}

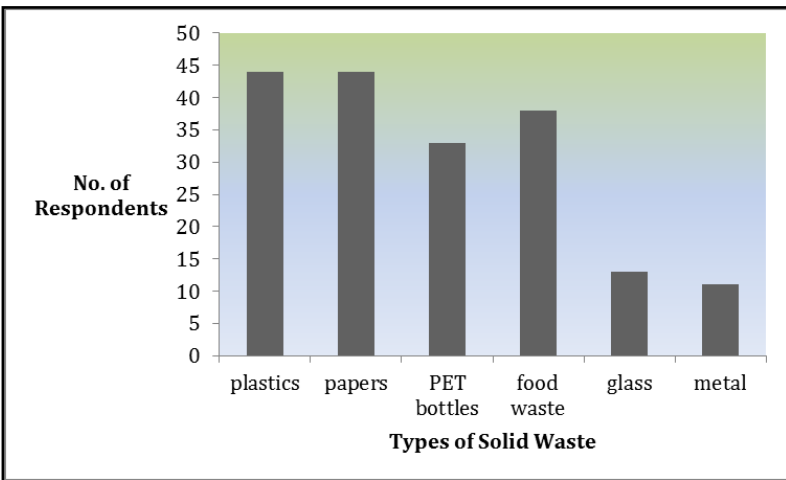

Fig. 2: Types of SW generated in public secondary schools

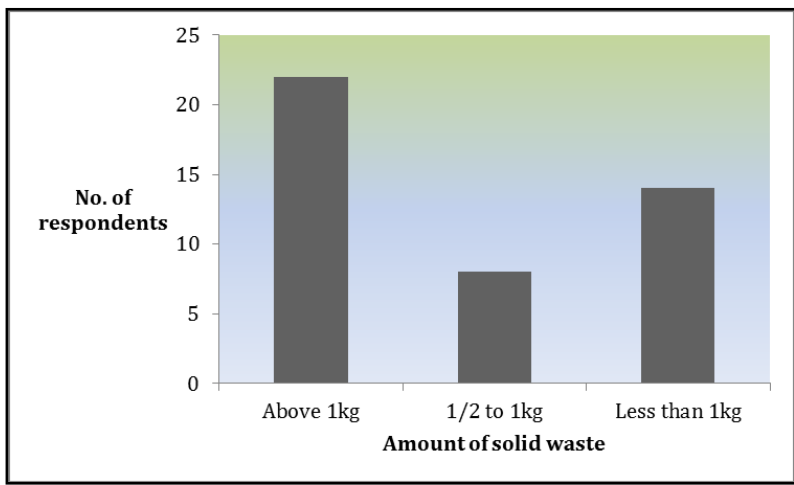

Fig. 3: Estimated amount of SW generated in public secondary schools

Further, composting of SW ranked third as disposal method. Composting activities is mainly a tributary to the greening program of DepEd (DepEd Memorandum No. 58, s. 2011 'Creating the Task Force on National Greening Program') through establishing school gardens. Overall teachers were positively aware about SWM with majority able to practice SWM appropriately. Further, partial willingness towards SWM was marginal (Fig. 5) although policy frameworks are existing.

\subsection{Best practices}

Below are existing policy frameworks that DepEd and the LGUs had established to support SWM. These policies were implemented at certain level enabling institutional arrangements between public secondary schools, the LGUs, and the Department of Environment and Natural Resources (DENR):

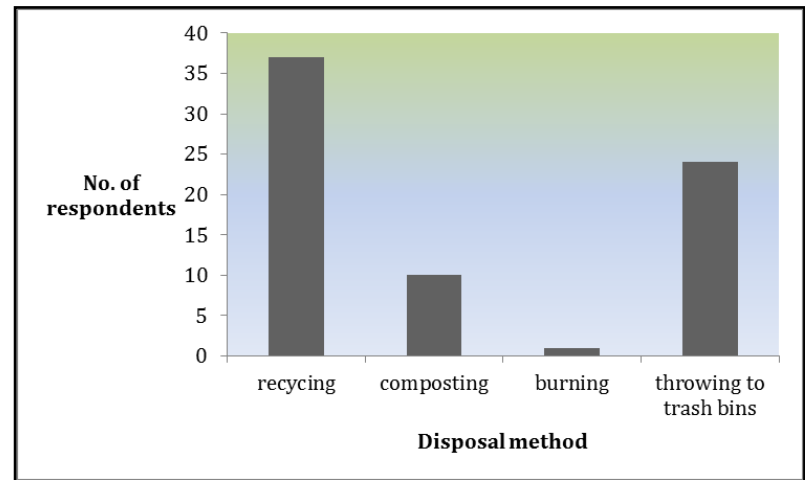

Fig. 4: Perceived SW disposal methods in public secondary schools

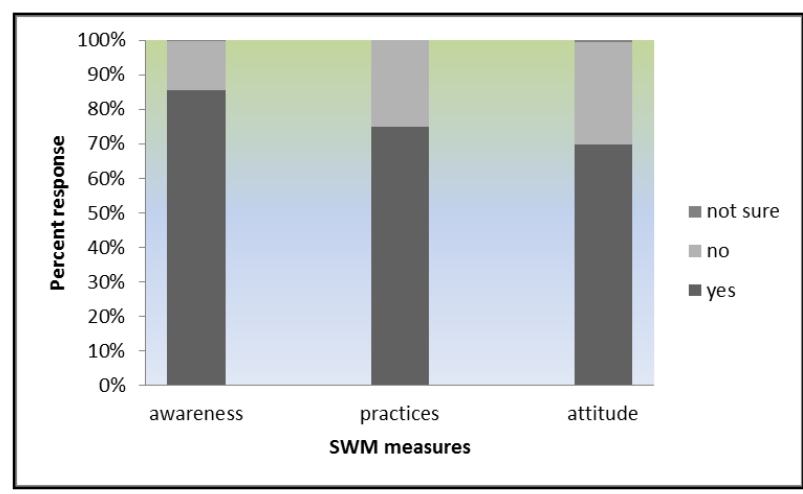

Fig. 5: Overall response of public secondary school teachers towards SWM

1. DepEd Memorandum No. 58, s. 2011- Creating the Task Force on National Greening Program,

2. DepEd Cagayan de Oro Memo 696 s. 2015 Participation in the Barangay Solid Waste Management and Waste Segregation,

3. DepEd Order 10 Series 2016-Policy and Guidelines for the Comprehensive Water, Sanitation and Hygiene in Schools (WinS) Program.

Public secondary schools also organized student based organization named "Youth Environment in Schools-Organization". This primarily acts as environmental stewards in respective schools to promote environmental awareness which include SWM.

Although conservative in numbers, some public secondary schools practiced recycling of PET bottles. Mainly bins for recyclables were placed adjacent to school gates and canteens (Fig. 6 and Fig. 7). 
Likewise, this practice may stimulate positive attitude towards recycling, reducing, and reusing (Ivy et al., 2013; Malakahmad et al., 2010; Omran et al., 2009).

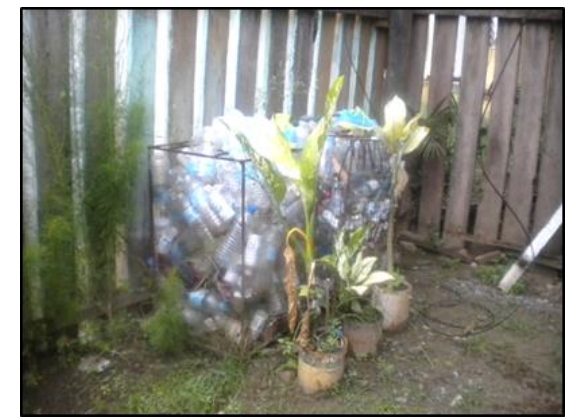

Fig. 6: Waste Bin for PET bottles in Bonbon National High School

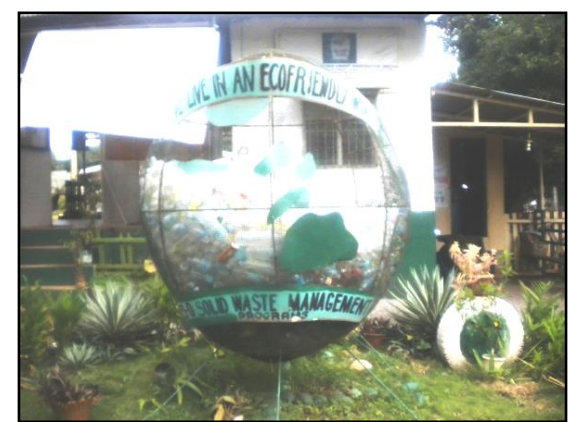

Fig. 7: Waste Bin for PET bottles in Lumbia National High School

\subsection{Gaps and recommendations}

During the school visit and ocular inspection some schools do not have appropriate SW bins (Fig. 8 and Fig. 9) although they practice clean and greening program. It was evident that waste containers provided caters mixed organic and plastics. Selected public secondary schools lack the following:

1. Appropriate SW bins for biodegradable and nonbiodegradable

2. Recycling bins

3. MRF and composting facility

4. Signage to encourage SWM

5. Curriculum instruction integration SWM

These are recommended to encourage the teachers and students to be involved in SWM.

\section{Conclusion}

Overall, the mandate of RA 9003 and DepEd policy frameworks for SWM were marginally implemented in public secondary schools in Cagayan de Oro, Philippines. This was evidenced by the survey response of science teacher's positive level of awareness, attitude, and practices towards SWM. The ocular visit to the respective schools similarly confirmed surveyed teachers response. Some schools however were selectively able to practice SWM better through integration of recycling and compositing. Despite the available alternative SWM option it was evident that MRF and SWM consistency implementation were absent. Extrapolating from this it can be inferred that most schools failed to implement completely RA 9003 although positive responses were recorded. Present findings should be the basis for policy making to ensure enforcement of RA 9003 in public secondary schools.

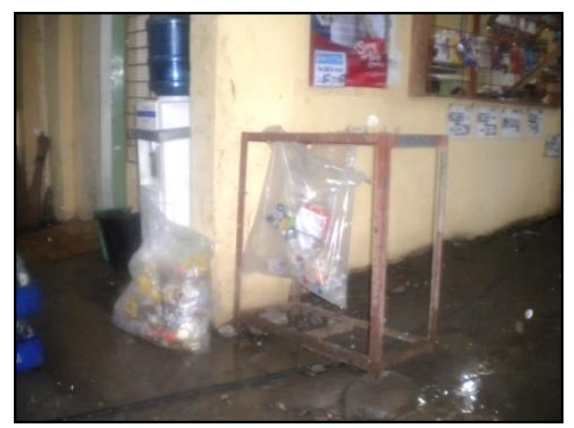

Fig. 8: Waste Bin in PN Roa Sr. National High School

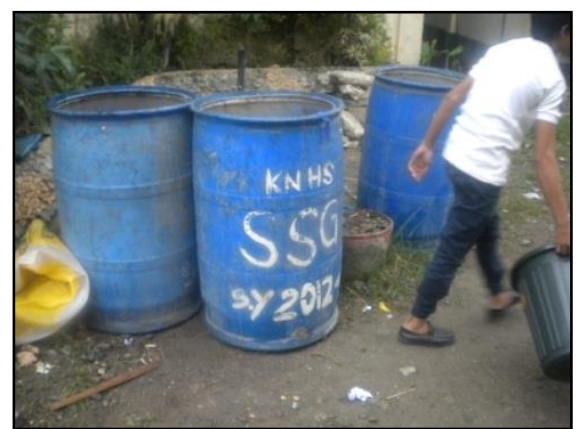

Fig. 9: Waste Bins in Kauswagan National High School

\section{References}

Babaei AA, Alavi N, Goudarzi G, Teymouri P, Ahmadi K, and Rafiee $M$ (2015). Household recycling knowledge, attitudes and practices towards solid waste management. Resources, Conservation and Recycling, 102: 94-100.

Begum RA, Siwar C, Pereira JJ, and Jaafar AH (2009). Attitude and behavioral factors in waste management in the construction industry of Malaysia. Resources, Conservation and Recycling, 53(6): 321-328.

Bernardo EC (2008). Solid-waste management practices of households in Manila, Philippines. Annals of the New York Academy of Sciences, 1140(1): 420-424.

Cortez LAS and Ching JA (2014). Heavy metal concentration of dumpsite soil and accumulation in Zea mays (corn) growing in a closed dumpsite in Manila, Philippines. International Journal of Environmental Science and Development, 5(1): 77-80.

Cruz JP and Tantengco NS (2017). Students' environmental awareness and practices: Basis for development of advocacy program. Mimbar Pendidikan, 2(1): 43-64.

Cultura MV, Aranico EC, Vedra SA, and Amparado Jr RF (2013). Utilization and management of electronic goods by different households in Cagayan de Oro City, Philippines. Advances in Environmental Sciences, 5(3): 316-324.

De Vega CA, Benítez SO, and Barreto MER (2008). Solid waste characterization and recycling potential for a university campus. Waste Management, 28: S21-S26.

De Vega CA, Ojeda-Bení S, and Ramí ME (2003). Mexican educational institutions and waste management programmes: a University case study. Resources, Conservation and Recycling, 39(3): 283-296. 
Ejares JA, Paler MKO, and Aguilar MEL (2014). Socio-Demographic profile of scavenging households in umapad dumpsite, mandaue city Cebu, Philippines. Journal of Sustainable Development Studies, 6(1): 175-192.

Elemile 00 and Benjamin OR (2011). Solid waste management problems in secondary schools in Ibadan, Nigeria. Journal of Environmental Health, 74(2): 24-28

Felder MA, Petrell RJ, and Duff SJ (2001). A solid waste audit and directions for waste reduction at the University of British Columbia, Canada. Waste Management and Research, 19(4): 354-365.

Galarpe VRK (2015). Socio-demographic assessment of surrounding community to a material recovery facility (MRF) and a dumpsite: The case of Lapu-Lapu City, Philippines. Journal of Sustainable Development Studies, 8(2): 260-274.

Galarpe VRK and Parilla RB (2012). Influence of seasonal variation on the biophysicochemical properties of leachate and groundwater in Cebu City Sanitary Landfill, Philippines. International Journal of Chemical and Environmental Engineering, 3(3): 175-181.

Galarpe VRK and Parilla RB (2014). Opportunities and Threats to Adjacent Community in a Sanitary Landfill, Philippines. Environment Asia, 7(1): 112-125.

Ifegbesan A (2010). Exploring secondary school students understanding and practices of waste management in Ogun State, Nigeria. International Journal of Environmental and Science Education, 5(2): 201-215.

Ifegbesan A (2011). Waste management awareness, knowledge, and practices of secondary school teachers in Ogun state, Nigeria-Implications for teacher education. The Journal of Solid Waste Technology and Management, 37(3): 221-234.

Imam A, Mohammed B, Wilson DC, and Cheeseman CR (2008). Solid waste management in Abuja, Nigeria. Waste Management, 28(2): 468-472.

Ivy N, Uddin MM, and Hossain MK (2013). People's perception on using waste bins in reduce, reuse and recycle (3Rs) process for solid waste management (SWM) in Chittagong Bangladesh. International Journal of Applied Science, Technology and Engineering Research, 2(3): 30-40.

Kelly TC, Mason IG, Leiss MW, and Ganesh S (2006). University community responses to on-campus resource recycling. Resources, Conservation and Recycling, 47(1): 42-55.

Licy CD, Vivek R, Kamath Saritha TK, and Josphina CT (2013). Awareness, attitude and practice of school students towards household waste management. Journal of Environment, 2(6): 147-150.
Liu SY, Yeh SC, Liang SW, Fang WT, and Tsai HM (2015). A national investigation of teachers' environmental literacy as a reference for promoting environmental education in Taiwan. The Journal of Environmental Education, 46(2): 114-132.

Malakahmad A, Nasir MZM, Kutty SR, and Isa MH (2010). Solid waste characterization and recycling potential for university technology PETRONAS academic buildings. American Journal of Environmental Sciences, 6(5): 422-427.

Mason IG, Brooking AK, Oberender A, Harford JM, and Horsley PG (2003). Implementation of a zero waste program at a university campus. Resources, Conservation and Recycling, 38(4): 257-269

Mbuligwe SE (2002). Institutional solid waste management practices in developing countries: a case study of three academic institutions in Tanzania. Resources, Conservation and Recycling, 35(3): 131-146

Omran A, Mahmood A, Abdul Aziz H, and Robinson GM (2009). Investigating households attitude toward recycling of solid waste in Malaysia: A case study. International Journal of Environmental Research, 3(2): 275-288.

Paul JG, Arce-Jaque J, Ravena N, and Villamor SP (2012). Integration of the informal sector into municipal solid waste management in the Philippines-What does it need?. Waste Management, 32(11): 2018-2028.

Smyth DP, Fredeen AL, and Booth AL (2010). Reducing solid waste in higher education: The first step towards 'greening'a university campus. Resources, Conservation and Recycling, 54(11): 1007-1016.

Su GLS (2008). Assessing the effect of a dumpsite to groundwater quality in Payatas, Philippines. American Journal of Environmental Sciences, 4(4): 276-280.

Su GS (2005). Water-borne illness from contaminated drinking water sources in close proximity to a dumpsite in Payatas, the Philippines. Journal of Rural and Tropical Public Health, 4: 4348.

Ugulu I, Sahin M, and Baslar S (2013). High school students' environmental attitude: scale development and validation. International Journal of Educational Sciences, 5(4): 415-424.

Zurbrugg C (2002). Urban solid waste management in low-income countries of Asia: How to cope with the garbage crisis. In the Scientific Committee on Problems of the Environment (SCOPE) Urban Solid Waste Management Review Session, Durban, South Africa: 1-13. Available online at: http://www.eawag.ch/fileadmin/Domain1/Abteilungen/sand ec/publikationen/SWM/General_Overview/Zurbruegg_2003_ Crisis.pdf 